\title{
A technique for measuring the biological availability of copper to sheep, using hypocupraemic ewes
}

\author{
By N. F. SUTTLE \\ Moredun Research Institute, Gilmerton Road, Edinburgh EHI7 $7 \mathscr{F H}$ \\ (Received 1o December 1973 - Accepted 19 February 1974)
}

\begin{abstract}
I. Ewes were made hypocupraemic by feeding a copper-deficient diet and the subsequent responses in plasma $\mathrm{Cu}$ obtained when $\mathrm{Cu}$ was added to the diet were used to assess the biological availability of the added $\mathrm{Cu}$.

2. The uniformity of responses was investigated by repleting thirty-six ewes for $33 \mathrm{~d}$ on two occasions with a standard diet containing $5.0 \mathrm{mg} \mathrm{Cu} / \mathrm{kg}$ dry matter (DM). The mean responses were 0.36 and $0.33 \mathrm{mg} / \mathrm{l}$ and the coefficient of variation was approximately $53 \%$ on each occasion. The marked individual differences were largely repeatable, the correlation coefficient $(r)$ within individuals being $0.68(P<0.001)$.

3. A dose : response relationship was investigated by giving five groups of seven ewes diets containing $2 \cdot 7,4 \cdot 2,5 \cdot 7,7 \cdot 2$ or $8 \cdot 7 \mathrm{mg} \mathrm{Cu} / \mathrm{kg}$ oM for $33 \mathrm{~d}$. Each increment in dietary $\mathrm{Cu}$ above $4.2 \mathrm{mg} / \mathrm{kg}$ significantly increased the response in plasma $\mathrm{Cu}$. The relationship between plasma $\mathrm{Cu}$ response $(y, \mathrm{mg} / \mathrm{l})$ and $\mathrm{Cu}$ intake $(x, \mathrm{mg} / \mathrm{d})$ after $2 \mathrm{I} \mathrm{d}$ was $y=0.087 \mathrm{I} x-0.250$ $(r=0.99 ; 3 \mathrm{df})$.

4. The source of individual variation was investigated by comparing the responses of three 'slow' and three 'fast' responding ewes from Expt $\mathrm{I}$ to $\mathrm{Cu}$ given as a continuous intravenous

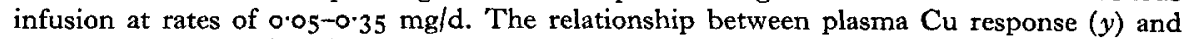
infusion rate $(x, \mathrm{mg} / \mathrm{d})$ after $\mathrm{I} 7 \mathrm{~d}$, was $y=2.135 x-0.156(r=0.86 ; P<0.00 \mathrm{I})$. The regression coefficients for 'slow' and 'fast' responding ewes were similar, as was their metabolism of intravenous ${ }^{64} \mathrm{Cu}$, suggesting that the individual differences were due to differences in absorption rather than in the metabolism of absorbed $\mathrm{Cu}$. Faecal endogenous $\mathrm{Cu}$ excretion was estimated to be $0.127 \pm 0.019$ (mean $\pm \mathrm{SE}$ ) $\mathrm{mg} / \mathrm{d}$.

5. The relative responses to oral and intravenous $\mathrm{Cu}$ were used to estimate the true availability of dietary $\mathrm{Cu}$; in one experiment it was $4.1 \%$ and for individual ewes in another experiment, availabilities ranged from 4.5 to $I I .4 \%$. The figures are compared with assessments by conventional techniques.

6. It is concluded that the repletion technique provides a sensitive means of assessing the availability of $\mathrm{Cu}$ in ruminant diets.
\end{abstract}

The copper nutrition of sheep is unique in that diets of similar $\mathrm{Cu}$ content can produce clinical symptoms of deficiency (Allcroft \& Lewis, 1957) and of excess (Hogan, Money \& Blayney, 1968; Suttle, I968; Adamson, Valks, Appleton \& Shaw, 1969). The factors responsible for the marked differences in $\mathrm{Cu}$ retention in these contrasting conditions are unlikely to be discovered until new techniques for measuring the biological availability of dietary $\mathrm{Cu}$ are developed. Conventional balance techniques are inadequate because only a small proportion of the $\mathrm{Cu}$ ingested by sheep (10\% or less) is absorbed and differences in absorption can easily be masked by analytical errors (Mills \& Williams, r971). The biological availability of $\mathrm{Cu}$ to non-ruminants has frequently been assessed from the responses of initially $\mathrm{Cu}$-deficient animals to repletion with different sources of $\mathrm{Cu}$. Schulze, Elvehjem \& Hart (1936) thus showed that the $\mathrm{Cu}$ in copper sulphide and copper porphyrin was less readily utilized by rats than that given as the oxide, citrate and pyrophosphate; similar techniques have recently been used by Kirchgessner \& Grassmann (I970) to assess the availabilities 
of different $\mathrm{Cu}$-amino acid complexes to rats. An attempt has, therefore, been made to apply the principle of the repletion technique to the more difficult problem of measuring the availability of $\mathrm{Cu}$ in the diet of ruminants, which are generally thought to utilize dietary $\mathrm{Cu}$ far less efficiently than non-ruminants.

\section{EXPERIMENTAL}

Animals

Thirty-six Scottish Blackface ewes, 7-9 years old, weighing 40-59 kg, from a single source (Animal Breeding Research Organization, Stanhope) were used.

\section{Housing}

Ewes were individually housed in pens described by Suttle \& Field (1968) during oral repletion (Expts I and 2). During depletion, some were kept in groups out of doors in pens with wooden partitions and slatted floors. For the intravenous infusion studies (Expt 3), ewes were contained in metabolism crates constructed from mild steel (J. J. Robinson, personal communication) coated with polyurethane paint and lined with fibreglass panels. A supply of deionized water was available to all sheep.

\section{Diets}

Animals were depleted of $\mathrm{Cu}$ by feeding them $0.72 \mathrm{~kg}$ dry matter (DM)/d of a semipurified diet (Suttle $\&$ Field, 1968 ) containing on average I. $2 \mathrm{mg} \mathrm{Cu} / \mathrm{kg}, 0.3 \mathrm{mg}$ molybdenum $/ \mathrm{kg}$ and $3.5 \mathrm{~g}$ sulphur $/ \mathrm{kg}$ on a DM basis.

\section{Expt I}

Preliminary experiments indicated that there were marked differences between individual $\mathrm{Cu}$-depleted sheep in the way they responded during $\mathrm{Cu}$ repletion. This experiment was, therefore, designed to assess the uniformity and repeatability of the repletion response and identify some components of variation.

Oral repletion procedure. When individual sheep attained plasma $\mathrm{Cu}$ values below $0.35 \mathrm{mg} / \mathrm{l}$, they were repleted by adding $4 \mathrm{mg} \mathrm{Cu} / \mathrm{kg}$ as $\mathrm{CuSO}_{4} \cdot{ }_{5} \mathrm{H}_{2} \mathrm{O}$ to the basal diet. For convenience, ewes were repleted in groups of four to eight. Individuals attaining plasma $\mathrm{Cu}$ values below $0.25 \mathrm{mg} / \mathrm{l}$ before a group had been formed were maintained on a 'standby' diet containing a supplement of $1 \mathrm{mg} \mathrm{Cu} / \mathrm{kg}(2 \cdot 2 \mathrm{mg}$ total $\mathrm{Cu} / \mathrm{kg}$ ) in order to minimize the variation in initial $\mathrm{Cu}$ status. Ewes were repleted for $33 \mathrm{~d}$ on two occasions, the low-Cu diet being given between the repletion phases. The experiment lasted 7 months and it was necessary to prepare nine batches of repletion diet using different consignments of raw materials; they had a mean $\mathrm{Cu}$ concentration of $5 \cdot 0 \pm 0.27(\mathrm{sD}) \mathrm{mg} / \mathrm{kg}$.

Plasma samples were obtained for $\mathrm{Cu}$ analysis at weekly intervals throughout the experiment. Haemoglobin in whole blood and direct-reacting $\mathrm{Cu}$ (Underwood, 1971) in plasma were estimated on days 0 and 33 of each repletion phase, and a single measurement of plasma volume was made in the middle of the experiment. 


\section{Expt 2}

The object of the experiment was to test the ability of the repletion technique to detect small increments in dietary $\mathrm{Cu}$ concentration.

Oral repletion procedure. Five groups of seven $\mathrm{Cu}$-depleted ewes were given the basal diet supplemented with $\mathrm{Cu}$ to provide $2 \cdot 7,4 \cdot 2,5 \cdot 7,7 \cdot 2$ or $8 \cdot 7 \mathrm{mg}$ total $\mathrm{Cu} / \mathrm{kg}$ for $33 \mathrm{~d}$. The diets contained on average $0.5 \mathrm{mg}$ Mo and $3.0 \mathrm{~g} \mathrm{~S} / \mathrm{kg}$. Ewes were drawn from the pool used for Expt I, supplemented by five 2-year-old ewes of the same breed and from the same source. Individuals were ranked in order of the responses in plasma $\mathrm{Cu}$ recorded after $33 \mathrm{~d}$ repletion with the diet used in Expt $\mathrm{I}:$ the ranking list was then divided serially into blocks of five and treatments were allocated to ewes at random within blocks.

All ewes commenced repletion simultaneously, those previously attaining plasma $\mathrm{Cu}$ values $<0.25 \mathrm{mg} / \mathrm{l}$ being given the 'standby' diet prior to repletion. Plasma $\mathrm{Cu}$ and caeruloplasmin concentrations were assessed weekly.

\section{$\operatorname{Expt} 3$}

A wide range of individual responses to repletion was observed in Expt $\mathrm{I}$; these could have arisen from differences in either the absorption of $\mathrm{Cu}$ or the metabolism of absorbed $\mathrm{Cu}$. Three animals from each extreme of the oral response distribution in Expt I were, therefore, depleted of $\mathrm{Cu}$ and repleted by means of a continuous intravenous infusion of $\mathrm{Cu}$ to see if the differences were still manifested when the gut was by-passed.

Intravenous repletion procedure. PVC catheters (o.d. $2 \mathrm{~mm}$, i.d. I $\mathrm{mm}$ ) were placed in the jugular vein and secured by thread to Michaelis clips at the point of insertion in the neck. Infusion solutions were pumped to each catheter by a multi-channel peristaltic pump (Quickfit Instrumentation Ltd, Stone, Staffs.) delivering approximately $200 \mathrm{ml} / \mathrm{d}$ for periods of $\mathrm{I}_{7}-30 \mathrm{~d}$. Each infusate consisted of saline $(9 \mathrm{~g} \mathrm{NaCl} / \mathrm{l})$ containing $0.25^{-\mathrm{I}} \cdot 5 \mathrm{mg} \mathrm{Cu} / \mathrm{l}$, as $\mathrm{CuSO}_{4} \cdot \mathrm{H}_{2} \mathrm{O}$, and adjusted to $\mathrm{pH} 4$ with $\mathrm{H}_{2} \mathrm{SO}_{4}$. To minimize the risk of infection, sterile saline was used, the supply lines were flushed with sodium 2-(ethylmercurithio)benzoate solution ( $\mathrm{g} / \mathrm{l}$ ) prior to infusion and a $0.45 \mu \mathrm{m}$ filter unit (Millipore (UK) Ltd, London) was incorporated in each line. Pumping rates varied slightly from sheep to sheep and were estimated from the total volume infused. All ewes received the low-Cu diet, providing I-I $\mathrm{mg} \mathrm{Cu} / \mathrm{d}$ throughout; depletion, therefore, commenced as each infusion was terminated.

${ }^{64} \mathrm{Cu}$ was infused intravenously into three 'fast' and three 'slow' responding ewes on the $27^{\text {th }}$ day of a trial in which approximately $0.25 \mathrm{mg} \mathrm{Cu} / \mathrm{d}$ was infused. The infusate was temporarily drawn from a small polystyrene tube containing $2 \mathrm{mCi}$ ${ }^{64} \mathrm{CuCl}_{2}$ (Radiochemical Centre, Amersham, Bucks.) in a total volume of $8 \mathrm{ml}$. The isotope was estimated to have entered the bloodstream over a period of approximately I h. Total collections of faeces and urine were made for $3 \mathrm{~d}$ after dosing. Urine was collected via bladder catheters in Pyrex vessels containing $100 \mathrm{ml} \mathrm{I} \mathrm{M-HCl}$, and duplicate samples of $\mathrm{I}_{5} \mathrm{ml}$ were retained for counting. Faeces were collected daily in polypropylene buckets, mixed in a domestic food mixer and duplicate samples of 
10-I $5 \mathrm{~g}$ fresh weight were retained for counting. Blood samples were obtained at frequent intervals. Finally, a sample of liver tissue was removed from the dorsal lobe by aspiration biopsy $70 \mathrm{~h}$ after dosing. Counting techniques were generally those given by Smith, Field \& Suttle (1968). Each sample was counted twice, the coefficient of variation for consecutive counts of the same sample was $1 \cdot 9 \%(n=12)$, and the least active samples (urine on day 3 ) were 60 counts/min above background and were counted for $6.7 \mathrm{~min}$.

\section{Analytical methods}

Plasma $\mathrm{Cu}$ was estimated by atomic absorption spectrophotometry (AAS). Plasma was diluted $\mathrm{I}: \mathrm{I}(\mathrm{v} / \mathrm{v})$ with glass-distilled water in Expt $\mathrm{I}$ and $\mathrm{I}: 2(\mathrm{v} / \mathrm{v})$ with $n$-butanol, $80 \mathrm{~g} / \mathrm{l}$, in Expts 2 and 3, prior to aspiration. The standards consisted either of a series of natural plasmas or a low-Cu plasma with standard additions of inorganic $\mathrm{Cu}$. $\mathrm{Cu}$ in standards was determined in triplicate by AAS after wet digestion of the sample, addition of $\mathrm{I} \mathrm{ml}$ ammonium pyrrolidine dithiocarbamate (APDC; $\mathrm{I} \mathrm{g} / \mathrm{l}$ ) and extraction of the $\mathrm{Cu}-\mathrm{APDC}$ complex into amyl acetate; $\mathrm{Cu}$ in urine was determined by a similar method but acidification to $\mathrm{pH} 3$ with $\mathrm{r} \mathrm{M}-\mathrm{HCl}$ replaced the acid-digestion stage. Direct-reacting $\mathrm{Cu}$ in plasma and $\mathrm{Cu}$ in diets and faeces were estimated by the methods of Suttle \& Field (1968). Dietary Mo was determined by the method of Bingley (1959) and total dietary $\mathrm{S}$ by a method based on that of Garrido (1964) but using the digestion method of Mottershead (r97r).

Caeruloplasmin was determined by its oxidase activity towards $p$-phenylenediamine, using a flow system and purified sheep caeruloplasmin standards as described by Smith \& Wright (1974): results were converted into I.U. (Rice, 1962) on the basis that one I.U. was equivalent to ${ }_{1} \cdot 6 \mu \mathrm{g}$ sheep caeruloplasmin. Haemoglobin was estimated as cyanmethaemoglobin (Hainline, 1958), using proprietary standards (Boehringer Ltd, London) for reference. The method of Chinard (I95I) was used for estimating plasma volume.

\section{Statistics}

Individual responses in plasma $\mathrm{Cu}$ in Expt I were analysed by curvilinear regression techniques and multiple regression analysis was used to assess the relationship of age, live weight, initial total and direct-reacting plasma $\mathrm{Cu}$, plasma volume and initial haemoglobin level to the differences in repletion response between individuals. Expt 2 was analysed as a randomized block design (Snedecor, 1956). Most means are given with their standard errors, the exceptions being noted.

\section{RESULTS}

\section{Expt I}

Plasma Cu. In most ewes, plasma $\mathrm{Cu}$ increased linearly as the first period of repletion progressed but some individuals with small over-all responses showed an initial lag and a final plateau in their response curves. There was, however, remarkable variation in the individual responses (final - initial value) after $33 \mathrm{~d}$ and this is illustrated in Fig. I. Individual responses ranged from 0.08 to $0.76 \mathrm{mg} / 1$ with a mean 


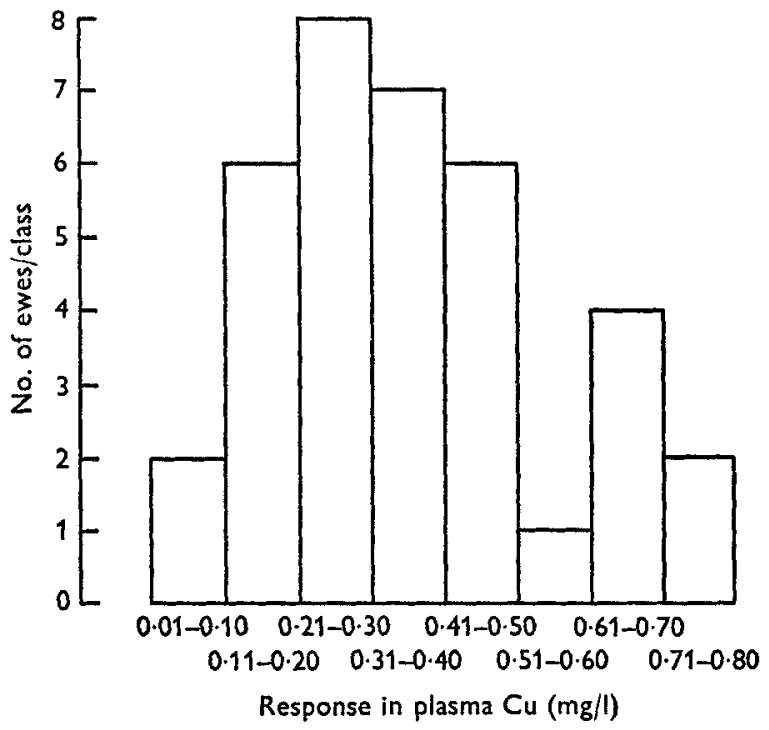

Fig. 1. Expt 1. A histogram of responses in plasma copper of individual hypocupraemic ewes to repletion for $33 \mathrm{~d}$ with a diet containing $5^{\circ} \mathrm{mg} \mathrm{Cu} / \mathrm{kg}$ dry matter.

response of $0.36 \pm 0.18(\mathrm{SD}) \mathrm{mg} \mathrm{Cu} / 1$. When the $\mathrm{Cu}$ supplement was withdrawn, plasma $\mathrm{Cu}$ values fell after $8 \mathrm{~d}$ in the majority of ewes and continued to fall at a relatively uniform rate of about $0.012 \mathrm{mg} \mathrm{Cu} / 1$ per $\mathrm{d}$ during depletion. The time taken for ewes to become sufficiently hypocupraemic for the second repletion to begin was inversely proportional to the response shown during the first repletion.

The over-all mean response for the second repletion phase was $0.33 \pm 0.19$ (SD) $\mathrm{mg} / \mathrm{l}$ and the individual responses ranged from -0.05 to $0.93 \mathrm{mg} / \mathrm{l}$. Responses of individual ewes for the two repletion periods were highly correlated $(r=0.675$; $P<0.001$ ), but multiple regression analysis failed to detect further significant components of variation, such as age, live weight, plasma volume, initial total or directreacting plasma $\mathrm{Cu}$, or initial haemoglobin level. The correlation between individual responses was not affected by comparing linear components of the response curve as opposed to final plasma $\mathrm{Cu}$-initial plasma $\mathrm{Cu}$ values.

Two sheep continued to show no response when the repletion was continued for $134 \mathrm{~d}$, indicating that the lack of response at $33 \mathrm{~d}$ was not merely a short-term phenomenon.

\section{Expt 2}

Plasma $\mathrm{Cu}$. The changes occurring in plasma $\mathrm{Cu}$ when groups of $\mathrm{Cu}$-depleted ewes were repleted on diets containing $2 \cdot 7-8 \cdot 7 \mathrm{mg} \mathrm{Cu} / \mathrm{kg}$ are illustrated in Fig. 2. At $\mathrm{Cu}$ concentrations of 2.7 or $4.2 \mathrm{mg} / \mathrm{kg}$ there was no repletion of the plasma Cu pool. Each increment of approximately $1.5 \mathrm{mg} \mathrm{Cu} / \mathrm{kg}$ above $4.2 \mathrm{mg} / \mathrm{kg}$, however, produced a significant increase in plasma $\mathrm{Cu}$ at some stage of repletion $(P<0.05)$. The response at each $\mathrm{Cu}$ level was essentially linear with a tendency for values to plateau towards the end of the experiment. The relationship between plasma Cu response $(y, \mathrm{mg} / \mathrm{l})$ and dietary $\mathrm{Cu}$ intake $(x, \mathrm{mg} / \mathrm{d})$ was also linear at each sampling time, the equation 


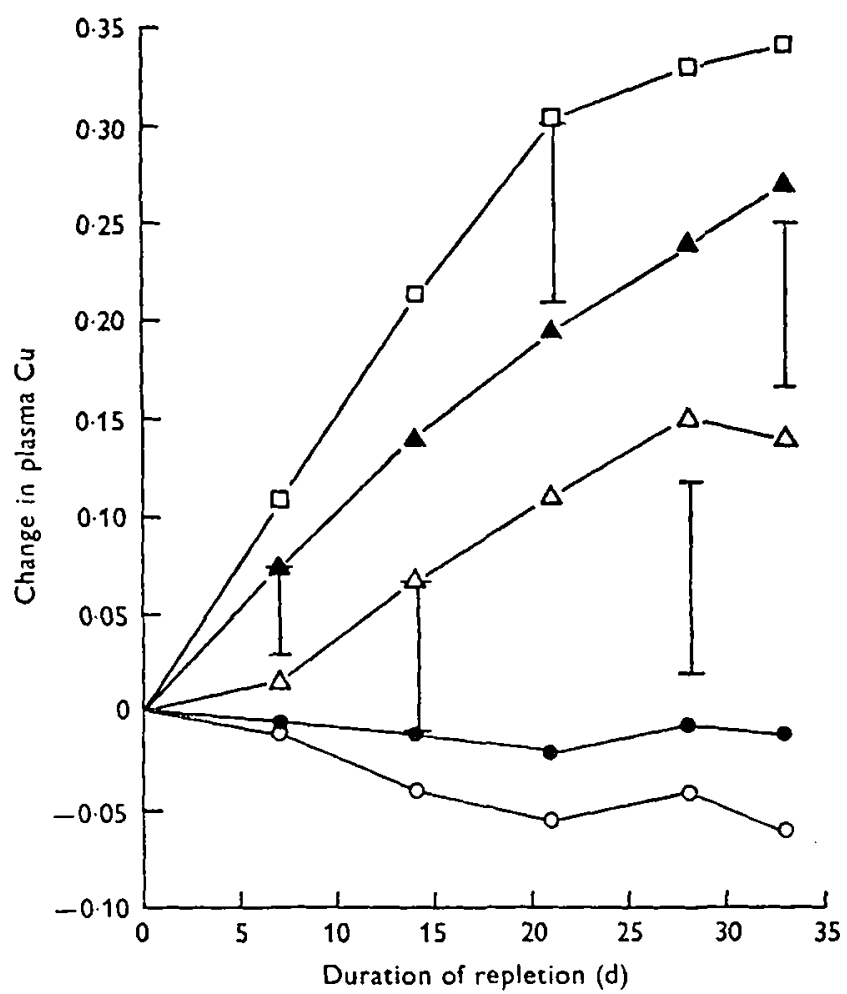

Fig. 2. Expt 2. Mean values for changes in plasma copper (mg/l) for groups of initially hypocupraemic ewes given diets containing $2 \cdot 7(0), 4 \cdot 2(O), 5 \cdot 7(\triangle), 7 \cdot 2(\Delta)$ or $8 \cdot 7(\square)$ $\mathrm{mg} \mathrm{Cu} / \mathrm{kg}$ for $33 \mathrm{~d}$. Vertical bar represents least significant difference $(P<0.05)$.

being $y=0.0871 x-0.250(r=0.99 ; 3 \mathrm{df})$ for day 21 , for example. The group given $2.7 \mathrm{mg} \mathrm{Cu} / \mathrm{kg}$ diet was subsequently given a diet containing $12.1 \mathrm{mg} \mathrm{Cu} / \mathrm{kg}$ to determine the approximate limit of the response curve and the mean response after $33 \mathrm{~d}$, $0.38 \pm 0.04 \mathrm{mg} / \mathrm{l}$, was not significantly greater than that obtained with $8.7 \mathrm{Cu} \mathrm{mg} / \mathrm{kg}$ diet. The relationship between the extended range of dietary $\mathrm{Cu}$ intakes and response in plasma $\mathrm{Cu}$ would be appropriately fitted by a sigmoid curve (Fig. 3).

The individual differences observed in Expt I were partly evident in Expt 2, blocks formed from the top and bottom of the ranking list of Expt 1 differing significantly from each other at each sampling $(P<0.05)$. Analysis of covariance with the uniformity trial responses was not possible, however, because there was virtually no correlation at the extremes of the dietary concentration range; the correlation coefficients $(r)$ were $0.20,0.27,0.34,0.79(P<0.05) 0.47$ and 0.12 for the groups given $2 \cdot 7,4 \cdot 2,5 \cdot 7,7 \cdot 2,8 \cdot 7$ and $\mathrm{I} 2 \cdot \mathrm{I} \mathrm{mg} \mathrm{Cu} / \mathrm{kg}$ diet, respectively.

The changes in caeruloplasmin copper reflected the changes in total plasma $\mathrm{Cu}$ during the first $21 \mathrm{~d}$ of the experiment. After $21 \mathrm{~d}$, however, responses were generally less than those in total plasma $\mathrm{Cu}$; values tended to plateau at 7.8 and $16.4 \mathrm{I}$. U./ for the groups given 5.6 and $7 \cdot 2 \mathrm{mg} / \mathrm{kg} \mathrm{Cu}$, respectively, and to decrease markedly from $3^{2.8}$ to 19.8 I.U. $/ 1$ after $33 \mathrm{~d}$ for the group given $8.7 \mathrm{mg} \mathrm{Cu} / \mathrm{kg}$.

Direct-reacting $\mathrm{Cu}$ in plasma was not measured. 


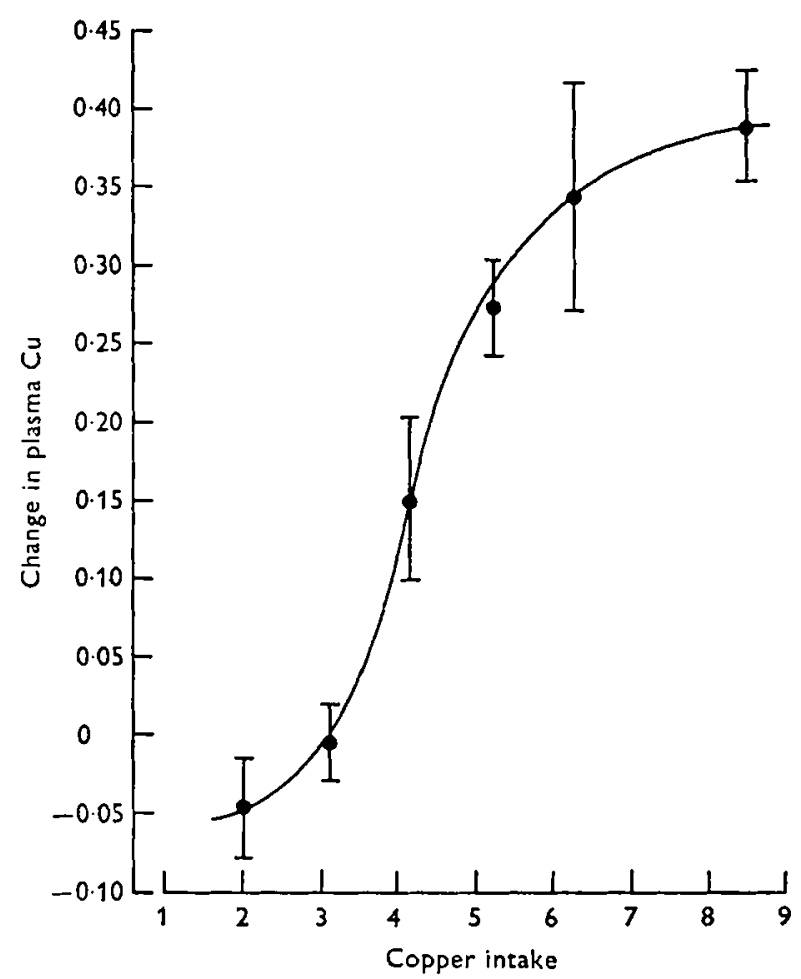

Fig. 3. Expt 2. Sigmoid relationship between copper intake (mg/d) and response in plasma $\mathrm{Cu}(\mathrm{mg} / \mathrm{l})$ of initially hypocupraemic ewes after $33 \mathrm{~d}$ repletion.

\section{Expt 3}

The two groups of ewes selected from the extremes of the response distribution in Expt $\mathrm{x}$ ('fast' or 'slow') showed essentially similar responses when supplementary $\mathrm{Cu}$ was given by intravenous infusion. The responses after $17 \mathrm{~d}$ are illustrated in Fig. 4 in which the over-all relationship between plasma response $(y, \mathrm{mg} \mathrm{Cu} / \mathrm{l})$ and $\mathrm{Cu}$ infused $(x, \mathrm{mg} / \mathrm{d})$ is given by the equation of $y=2 \cdot 135 x-0.156(r=0.86 ; 22 \mathrm{df})$. The regression equations calculated separately for the two groups were not significantly different. The response of the 'fast' group at the higher rates of infusion (approximately $0.3 \mathrm{mg} \mathrm{Cu} / \mathrm{d})$ was similar to that shown by these ewes in Expt I $(0.443 \pm 0.04 \mathrm{I} \mathrm{mg} / \mathrm{l})$.

The responses in caeruloplasmin $\mathrm{Cu}$ followed a similar pattern to that shown by total plasma $\mathrm{Cu}$, the linear relationship between caeruloplasmin response $(y, \mathrm{I} . \mathrm{U} . / 1)$ and infusion rate $(x, \mathrm{mg} / \mathrm{d})$ being described by the equation $y=126 \cdot 2 x-9 \cdot 8$ $(r=0.8 \mathrm{I})$. Caeruloplasmin accounted for approximately $68 \%$ of the response in total plasma $\mathrm{Cu}$.

The metabolism of the infusate labelled with ${ }^{64} \mathrm{Cu}$ was similar in the two groups. The results for stable and radioactive $\mathrm{Cu}$ excretion in urine and faeces are given in Table $\mathrm{I}$ and those for stable $\mathrm{Cu}$ and radioactive $\mathrm{Cu}$ in plasma and liver in Table 2. No significant differences were detected between 'slow' and 'fast' responding ewes for 


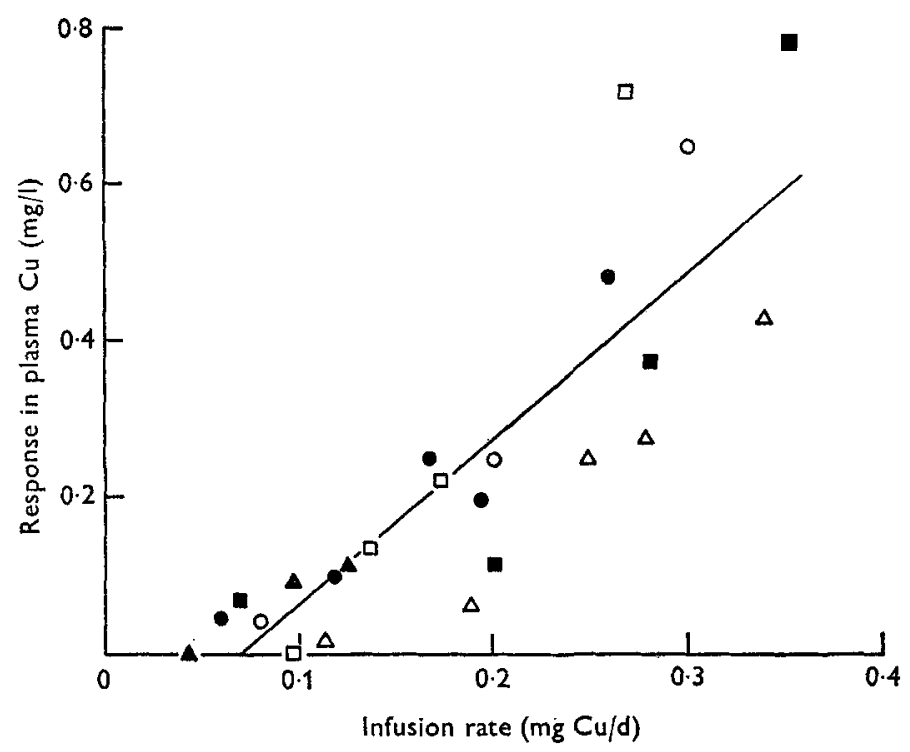

Fig. 4. Expt 3. Relationships between plasma copper response and $\mathrm{Cu}$ infusion rate in initially hypocupraemic ewes given a continuous intravenous infusion of $\mathrm{Cu}$ for $\mathrm{I} 7 \mathrm{~d}$. The relationship is given by the equation: $y=2.135 x-0.15^{6}(r=0.86)$, where $y$ is plasma $\mathrm{Cu}$ response and $x$ is $\mathrm{Cu}$ infusion rate. Three ewes had shown 'slow' $(O, \triangle, \square)$ and three ewes 'fast' responses $(\boldsymbol{\Theta}, \boldsymbol{\Delta ,} \mathbf{\square})$ to oral $\mathrm{Cu}$ repletion in Expt $\mathrm{I}$.

Table $\mathrm{I}$. Mean stable copper $(\mu \mathrm{g} / \mathrm{d})$ and radioactive Cu-balance $(\%$ dose/d) results for three 'slow' and three 'fast' repleting ewes on a low-Cu diet and receiving $0.25 \mathrm{mg} C \mathrm{Cu} / \mathrm{d}$ by continuous intravenous infusion

(Mean values and standard deviations)

\begin{tabular}{|c|c|c|c|c|c|}
\hline \multirow{3}{*}{$\begin{array}{l}\text { Response to } \\
\text { standard oral } \mathrm{Cu} \\
\text { supplement }\end{array}$} & \multicolumn{4}{|c|}{ Excretion* } & \multirow{3}{*}{$\begin{array}{c}\text { Endogenous } \uparrow \\
\text { faecal Cu } \\
(\mu \mathrm{g} / \mathrm{d})\end{array}$} \\
\hline & \multicolumn{2}{|c|}{ Stable $\mathrm{Cu}$} & \multicolumn{2}{|c|}{ Radioactive Cu } & \\
\hline & Urine & Faeces & Urine & Faeces & \\
\hline Slow & $43.1 \pm 13.8$ & $890 \pm 108$ & $0.40 \pm 0.10$ & $1 \cdot 34 \pm 0.37$ & $108.9 \pm 2.6$ \\
\hline Fast & $51 \cdot 2 \pm 20.9$ & $753 \pm 59$ & $0.47 \pm 0.19$ & I.10 \pm 0.35 & $144.3 \pm 39.2$ \\
\hline
\end{tabular}

* Urine and faeces were collected for $3 \mathrm{~d}$ after dosing with ${ }^{64} \mathrm{Cu}$.

$\uparrow$ Estimated by faecal ${ }^{64} \mathrm{Cu} \div$ specific activity of urine $\mathrm{Cu}$.

Table 2. Mean stable and radioactive copper concentrations in plasma and liver in three 'slow' and three 'fast' repleting ewes on a low-Cu diet and receiving $0.25 \mathrm{mg} \mathrm{Cu} / \mathrm{d}$ by continuous intravenous infusion

(Mean values and standard deviations)

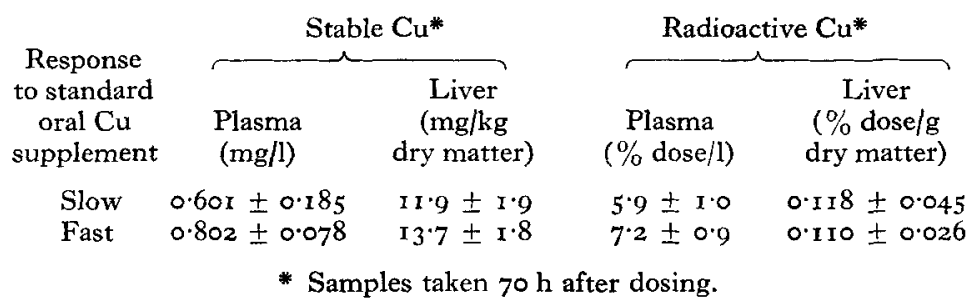


any of the measurements. The faecal endogenous loss of $\mathrm{Cu}$ was estimated from the specific activity of urine $\mathrm{Cu}$ between 24 and $72 \mathrm{~h}$ (Smith et al. $\mathrm{rg} 68$ ) to be $0.127 \pm$ $0.019 \mathrm{mg} / \mathrm{d}$.

\section{DISCUSSION}

The oral repletion techniques used by previous workers have measured the relative efficiency of $\mathrm{Cu}$ utilization for particular body functions, such as caeruloplasmin (Kirchgessner \& Grassmann, 1970) or haemoglobin synthesis (Mills, 1957), rather than the efficiency with which the element is removed from the diet (i.e. availability). By using oral and intravenous repletion techniques together, however, an assessment of availability can be made. Assuming that the jugular infusion of $\mathrm{Cu}$ adequately simulates the post-absorptive supply of $\mathrm{Cu}$, then the relationship between plasma $\mathrm{Cu}$ responses to oral and intravenous $\mathrm{Cu}$ provides a measure of the true availability of the dietary $\mathrm{Cu}$. Since one would expect a more immediate response to intravenous than to oral $\mathrm{Cu}$, regression coefficients for responses up to the $2 \mathrm{Ist}$ and $\mathrm{I} 7 \mathrm{th}$ days in Expts 2 and 3 were used ( $0.087 \mathrm{r}$ and $2.135 \mathrm{mg} \mathrm{Cu} / 1$ plasma per $\mathrm{mg} \mathrm{Cu}$ supplied, respectively) and a true availability of $4.1 \%$ was obtained; this is comparable with apparent availability values for similar diets of $2 \cdot 6 \pm \mathrm{I} \cdot 8 \%(n=7)$ obtained in mature Scottish Blackface wethers by stable-Cu balance technique (Smith et al. 1968) and $3.7 \pm 2 \cdot 1 \%$ $(n=3)$ in 3 -month-old Finnish Landrace lambs by a marker ratio technique (N. F. Suttle, unpublished results). The precision with which availability is predicted might be improved by extending the range of $\mathrm{Cu}$ inputs used and comparing the maximum slopes of the sigmoid responses to oral and intravenous $\mathrm{Cu}$.

The proposed method for measuring the availability of $\mathrm{Cu}$ is more sensitive than existing methods. Significant differences were obtained in Expt 2 between treatments differing by only $0.045 \mathrm{mg} / \mathrm{d}$ in the available $\mathrm{Cu}$ they provided. The analytical errors associated with conventional balance techniques would have prevented such differences from being detected (Mills \& Williams, 197I). The utilization of dietary Cu by ruminants has been frequently assessed from changes occurring in liver $\mathrm{Cu}$ stores, using the liver-biopsy technique to predict initial values (Dick, r953; Hartmans \& van der Grift, I965; Vanderveen \& Keener, I964; Hogan, Ris \& Hutchinson, I966). Assuming that all $\mathrm{Cu}$ apparently absorbed in Expt 2 would be retained in livers of $200 \mathrm{~g} \mathrm{DM}$, the increment of $0.045 \mathrm{mg} \mathrm{Cu} / \mathrm{d}$ would have increased liver $\mathrm{Cu}$ by only $0.2 \mathrm{mg} / \mathrm{kg}$ per $\mathrm{d}$. In view of the variation in $\mathrm{Cu}$ concentration within the liver (Hogan, Money \& Walker, 197I) and the errors in predicting liver weight from live weight, the differences recorded in Expt 2 would not have been detected by the liver-biopsy method.

The usefulness of the repletion technique for assessing $\mathrm{Cu}$ availability is limited by the sigmoid nature of the $\mathrm{Cu}$ intake $v$. plasma $\mathrm{Cu}$ response curve (Expt 2, Fig. 3), attributable to changes in either the efficiency of $\mathrm{Cu}$ absorption or in the metabolism of absorbed $\mathrm{Cu}$ at extreme $\mathrm{Cu}$ inputs. Since the responses to intravenous $\mathrm{Cu}$ also plateau outside the narrow range of concentrations studied in Expt 3 (N. F. Suttle, unpublished results), the non-linearity is probably attributable to changes in the rates of synthesis and destruction of $\mathrm{Cu}$ metabolites such as caeruloplasmin. In the past, the shape of the response curve has been ignored in assessing the availability of $\mathrm{Cu}$ by 
repletion techniques. Reliable estimates of availability will only be obtained, however, if conditions are arranged so that the supply of available $\mathrm{Cu}$ is within the linear part of the dose $v$. response curve. The conditions in Expt 2 were almost ideal, 3-9 mg Cu/ $\mathrm{kg}$ being the effective range of concentration with availability at $4 \%$ and food intake at $0.72 \mathrm{~kg} \mathrm{DM} / \mathrm{d}$. Had the availability of $\mathrm{Cu}$ been $8 \%$, the effective range would have been only $1 \cdot 4-4.5 \mathrm{mg} \mathrm{Cu} / \mathrm{kg}$. It is clear, therefore, that in applying the repletion technique to foodstuffs of relatively high $\mathrm{Cu}$ content, or availability or both, a different technique involving the partial substitution of the test diet in a basically $\mathrm{Cu}$-deficient ration would be required.

Individual variation is a further factor affecting the use of repletion techniques in studying $\mathrm{Cu}$ availability. When the method of $\mathrm{Cu}$ administration was changed from oral repletion (Expt I) to continuous intravenous infusion (Expt 3), individual differences in plasma $\mathrm{Cu}$ response were no longer evident, indicating that the different responses to oral repletion were due largely to differences in $\mathrm{Cu}$ absorption. The range of individual $\mathrm{Cu}$ availabilities was estimated from the oral and intravenous $\mathrm{Cu}$ inputs which gave similar plasma responses in the 'slow' and 'fast' groups of sheep. For example, at days $\mathrm{I} 9$ and $\mathrm{I} 7$ in Expts $\mathrm{I}$ and 3 respectively, inputs of $3.6 \mathrm{mg}$ oral $\mathrm{Cu}$ and $\mathrm{I} \cdot \mathrm{I} \mathrm{mg}$ oral $+0.12 \mathrm{I} \mathrm{mg}$ intravenous $\mathrm{Cu}$ both gave plasma responses of $0.052 \mathrm{mg} / \mathrm{l}$ in 'slow' responding ewes: Cu availability, $x$, was thus estimated (from equations of the type $2 \cdot 5 x=0.121$ ) to be $4.5 \%$ and $11 \cdot 4 \%$ for the two groups. Other studies have revealed marked differences between and within breeds of sheep in susceptibility to swayback and in the blood and liver $\mathrm{Cu}$ levels attained in a particular environment (Wiener \& Field, I970). Marked individual differences in $\mathrm{Cu}$ metabolism in sheep are, therefore, probably a widespread phenomenon.

Individual variation can be partly accommodated by conducting uniformity trials, like Expt I, and subsequently allocating animals to treatments on the basis of predetermined differences in response. The usefulness of this approach is limited by the extent of individual $v$. treatment interaction. In Expt 2, the difference in response between 'slow' and 'fast' responding ewes within each treatment group was greatest at the intermediate $\mathrm{Cu}$ concentration of $5.7 \mathrm{mg} / \mathrm{kg}$ and a good correlation was achieved with the responses obtained with a similar $\mathrm{Cu}$ concentration $(5.0 \mathrm{mg} / \mathrm{kg})$ in the uniformity trial. The more extreme treatments in Expt 2 gave poor correlations, however, presumably because some sheep were operating at the limits of their response curves. By closely matching the conditions in the uniformity trial and subsequent experiments, it might be possible to apply covariance analysis and achieve a greater reduction in the error sums of squares than the 50\% achieved in Expt 2 by removing the differences between blocks.

The differences between the mean availability $(4.1 \%)$ in Expt 2 and the range estimated for Expt I $(4 \cdot 5-\mathrm{II} 4 \%$ ) brings into question the reproducibility of repletion techniques. The difference is partly attributable to the use of different ewes in the two experiments, those used for Expt 2 having a mean uniformity trial response only $88 \%$ of those used in Expt I. The dietary Mo concentration in Expt I was unusually low and in view of the marked inhibiting effects which increments of $2-4 \mathrm{mg} \mathrm{Mo} / \mathrm{kg}$ can have on $\mathrm{Cu}$ availability in sheep (Suttle, I974), the higher Mo concentration in 
Expt $2(0.5 v .0 .3 \mathrm{mg} / \mathrm{kg})$ may be of significance. The availability of $\mathrm{Cu}$ in subsequent experiments was generally around $4 \%$ (Suttle, 1974).

The gross maintenance requirements of sheep for $\mathrm{Cu}$ have been estimated from balance studies (Murty, 1957) and from the regression of liver $\mathrm{Cu} v$. Cu intake (Abdellatif, 1968) to be $3.9-4.4 \mathrm{mg} \mathrm{Cu} / \mathrm{d}$. A net maintenance requirement of $0.170 \mathrm{mg} /$ $\mathrm{d}$ can be derived from the summation of metabolic faecal and urinary $\mathrm{Cu}$ excretion in Expt 3 . With availability estimated to be $4 \cdot \mathrm{I} \%$, the gross requirement becomes $4 \cdot \mathrm{mg} / \mathrm{d}$, which is in good agreement with the earlier estimates.

I would like to thank Dr A. C. Field for his advice and encouragement, Mr D. M. Pollock for preparing diets, Mrs M. MacDonald and Mr J. Cruickshank for tending the sheep, Mrs J. Williams and Mr J. Small for their technical assistance, and Mr R. Thompson (ARC, Unit of Statistics, Edinburgh) for analysing the results of Expt $\mathrm{r}$. $\mathrm{I}$ am also indebted to $\mathrm{Mr} \mathrm{B}$. Mitchell and Mr J. Williams who inserted the jugular catheters.

\section{REFERENCES}

Abdellatif, A. M. M. (1968). Versl. landbouwk. Onderz. Ned. No. 709, p. 76.

Adamson, A. H., Valks, D. A., Appleton, M. A. \& Shaw, W. B. (1969). Vet. Rec. 85, 368.

Allcroft, R. \& Lewis, G. (1957). F. Sci. Fd Agric. 8, s97.

Bingley, J. B. (1959). F. agric. Fd Chem. 7, 269.

Chinard, F. P. (195x). Meth. med. Res. 4, 38 .

Dick, A. T. (1953). Aust. vet. F. 29, 233.

Garrido, M. L. (1964). Analyst, Lond. 89, 6r.

Hainline, A. (1958). In Standard Methods of Clinical Chemistry Vol. 2, p. 49 [D. Seligson, editor]. New York: Academic Press.

Hartmans, J. \& van der Grift, J. (1965). Faarb. Inst. biol. scheik. Onderz. LandbGewass. p. 145.

Hogan, K. G., Money, D. F. L. \& Blayney, A. (1968). N.Z. Yl agric. Res. II, 435.

Hogan, K. G., Money, D. F. L. \& Walker, R. S. (1971). N.Z. fl agric. Res. 14, 132.

Hogan, P. K., Ris, D. R. \& Hutchinson, A. J. (I966). N.Z. Fl agric. Res. 9, 691.

Kirchgessner, M. \& Grassmann, E. (1970). Z. Tierphysiol. Tierernähr. Futtermittelk. 26, 340.

Mills, C. F. (1957). F. Sci. Fd Agric. 8, s88.

Mills, C. F. \& Williams, R. B. (r971). Proc. Nutr. Soc. 30, 83.

Mottershead, B. E. (I971). Lab. Pract. 20, $48_{3}$.

Murty, V. N. (1957). $\mathcal{~ . ~ s c i e n t . ~ i n d . ~ R e s . ~ C ~ 1 6 , ~} 121$.

Rice, E. W. (1962). Analyt. Biochem. 3, 452.

Schulze, M. D., Elvehjem, C. A. \& Hart, E. B. (1936). F. biol. Chem. rr5, 453.

Smith, B. S. W., Field, A. C. \& Suttle, N. F. (1968). F. comp. Path. 78, 449.

Smith, B. S. W. \& Wright, H. (1974). Clinica chim. Acta 50, 359.

Snedecor, G. W. (1956). Statistical Methods Applied to Experiments in Agriculture and Biology $5^{\text {th }}$ ed., p. 29r. Ames, Iowa: Iowa State College Press.

Suttle, N. F. (1968). In Proceedings of 2nd Nutrition Conference of Feed Manufacturers, Nottingham p. I50 [H. Swan and D. Lewis, editors]. London: J. and A. Churchill.

Suttle, N. F. (1974). Proc. 2nd int. Symp. Trace Element Metabolism in Animals, Wisconsin. (In the Press.)

Suttle, N. F. \& Field, A. C. (1968). F. comp. Path. 78, 35x.

Underwood, E. J. (I97I). Trace Elements in Human and Animal Nutrition $3^{\text {rd }}$ ed. p. 67. New York: Academic Press.

Vanderveen, J. E. \& Keener, H. A. (I964). F. Dairy Sci. 47, 1224.

Wiener, G. \& Field, A. C. (1970). In Trace Element Metabolism in Animals p. 92 [C. F. Mills, editor]. Edinburgh: E. and S. Livingstone. 